Habanik, J., Martosova, A., \& Letkova, N. (2020). The Impact of Managerial Decision-Making on Employee Motivation in Manufacturing Companies. Journal of Competitiveness, 12(2), 38-50. https://doi. org/10.7441/joc. 2020.02 .03

\title{
THE IMPACT OF MANAGERIAL DECISION-MAKING ON EMPLOYEE MOTIVATION IN MANUFACTURING COMPANIES
}

\section{- Jozef Habanik, Adriana Martosova, Natalia Letkova}

\begin{abstract}
In terms of competition, manufacturing companies are focusing more and more on employee performance as well as motivation, the latter of which seems to be a prerequisite for the long-term performance of employees and thus the sustainable success of the company. Managerial decision-making, another phenomenon gaining scientific attention, can be considered a challenging function and the most important activity of a manager. But what is the impact of managerial decision-making on the motivation of employees? Can managerial decision-making influence employee motivation? The aim of this paper is to investigate the impact of managerial decision-making on the motivation of employees in manufacturing companies. As the main method of data acquisition, a questionnaire survey among employees was conducted. For further processing and evaluation of the survey results, a contingency table and Chi-square test were used, followed by Student's T-test and F-test for calculating testability and verifying hypotheses. The results brought answers to the questions regarding the relationship between managerial decision-making and motivation of employees in the selected production companies. Factors and benefits affecting the motivation of employees and leading to their higher work performance was also determined, as well as to what extent a manager is able to influence performance.
\end{abstract}

Keywords: managerial decision making, manager, manufacturing company, employee motivation JEL Classification: M12, M54, L19

Received: August, 2019

1st Revision: February, 2020

Accepted: April, 2020

\section{INTRODUCTION}

The competitiveness of companies is currently of high interest to experts in various fields of scientific research. The higher the competition in the sector, the more difficult it is for companies to generate the required income from production factors and to use it at a sustainable level. Since we consider people to be the most valuable asset of any organization, it is logical that in order to succeed businesses must manage human capital in more efficient and sophisticated ways than their competitors in terms of obtaining maximum performance, commitment, creativity and loyalty from their employees. 
Human resources management, management and motivation lead to optimum productivity, employee working values and improved work performance in manufacturing companies (Boselie, 2014).

Human capital also refers to managers, i.e. the quality of their attitudes and decisions, as well as the way they manage human resources and influence employee motivation, thus contributing to the overall success of the business. Managers, representing an important component of organizations, are responsible for their own actions as well as for their subordinate employees, who are motivated by them to improve performance and work productivity. In the highly competitive environment in which most of today's businesses operate, it is necessary to continually search for new and more efficient management options in environments with a limited availability of resources. To achieve this, all parts of the manufacturing company must focus on improving and applying more efficient methods and variants under turbulently changing conditions. One of the important functions a manager performs in his/her work is decision-making, a process which involves choosing from a number of possible responses to stimuli and environmental impacts from the perspective of fulfilling the mission, intentions and goals for the future. The literature provides countless opinions and definitions of the concept of decision-making. Powell \& Buede (2009) outline three pillars in decision-making, with the first pillar the decision itself, the second pillar the decision-making process, and the last pillar the person who has the right and the agency to make decisions. According to Schwarz (2016), managers may decide to focus either on employees or on achieving a specified result. In the next chapter, we present a theoretical background featuring the current state of research into the issue from two perspectives - managerial decision-making and determinants of motivation. A separate aspect that should be taken into account is the specific environment of manufacturing companies, which may differ from other types of companies or public organizations.

\section{THEORETICAL BACKGROUND}

The research of Tabatabaei et al. (2019) deals with a new model of company decision-making based on BWM and its applications to managerial problems. They argue that the decision-making process is carried out by managers, who today prefer participative decision-making and management to address complex and challenging issues. The new BWM method offers favorable results using paired comparisons and mathematical models. Developed through an integrated model, in this paradigm collective decisions are arrived at. Through this model, they address two managerial issues, finding that their model delivers acceptable performance and greater reliability to organizations and manufacturing companies. According to Dionne et al. (2019) in particular, collective management decision-making is crucial in organizations. Their results show that in collective decision-making, employees produce more valuable ideas toward solving a problem than is the case with individual decision-making. In manufacturing companies, the manager must also think about increasing both the productivity of employee work as well as improving the quality of work, which brings strategies and techniques of motivation into the picture. Motivation was addressed directly in a study by Bratu \& Cioca (2019), who claimed that in order to motivate all members of their labor force in the most efficiency way, an organization must improve the lives of employees by modeling human behavior at work and facilitating social 
access among employees. They suggested game theory as an approach that managers can use in practice to identify strategies suitable for a working group of employees to increase welfare and productivity. In Japan, Bratu \& Cioca (2019) investigated the effects of job characteristics and job satisfaction on welfare among Japanese employees. Their research showed that employee welfare contributes to greater workplace performance. They also found that employee satisfaction is important in the workplace and is in fact the quality that mediates the relationship between job roles and positive well-being. These facts suggest that manufacturing companies cannot rely on job creation to promote employee welfare. What is imperative is employee satisfaction at work, a factor which plays a major role in the relationship between job creation and welfare (MagnierWatanabe et al., 2019). Kljajic-Dervic et al. (2019) claim that each manufacturing company seeks to streamline the production process in order to be competitive on domestic and international markets. One of the basic prerequisites for increasing the efficiency of the production process is the elimination of factors that limit its growth, among other things the lack of productivity of its employees. Permatasari et al. (2019) also analyzed the factor of human capital in manufacturing companies. Their data were collected through a questionnaire survey among 300 employees in two production companies. They found that the development of manufacturing companies had an impact not only on the availability of jobs, but on employee performance, employee satisfaction and employee well-being.

Nientied \& Toska (2019) dealt with the case of Albania and motivating knowledge workers. Little is known about the motivation of knowledge workers in the Western Balkans. The researchers argue that, while there is a widespread belief that finance and career opportunities are the most critical motivational factors, other internal motivational factors are also important. To better understand work motivation, a study was conducted among knowledge workers in Albania with a particular interest in internal and external motivation as well as organizational commitment. After reviewing the results, two motivational theories were chosen, namely self-determination theory and organizational commitment, along with the corresponding tools, range of work and internal motives. The survey was based on a dedicated homogeneous sample containing 252 valid questionnaires. After asking workers about their motivation, the investigators found that internal motivation factors were more important than external motivation factors. Given these results concerning motivational factors and organizational commitment, organizations should focus on devoting attention to the relationship between increased motivation and increased productivity.

Miao et al. (2019) found that although a link between public service motivation (PSM) and work performance in cases of increased attention was found, there is limited knowledge of the underlying mechanisms causing these effects. Using data from Chinese civil servants and supervisors, the authors have found that PSM leads to improved performance and organizational identification, as civil servants consider the organization's results to be important. Therefore, the researchers recommend that public agencies create an environment that helps employees identify with the organization, which contributes to their higher performance. In their research, Silva et al. (2019) focused on identifying factors that influence the decision-making of top managers of companies regarding occupational safety and health. Their research was carried out in 2018 and focused mostly on safety engineers in the region of Sao Paolo. Survey questionnaires brought 
244 valid responses, wherein the most important factors affecting the company's top managers in improving occupational safety are the risk that the organization will be monitored, found to be in violation of regulations and laws, and will thus be made to comply with them. Other factors included potential productivity gains, alomng with genuine interest in the employees and their health. Kocabiyikoglu \& Popescu (2007) explored the driving forces of managerial motivation, suggesting how organizations can use performance salary to change motivational patterns. Research has found that increased salary is not necessarily a motivating factor. Vojtovič (2016) dealt with the issue of managerial decision-making in manufacturing companies within a selected time horizon. It was important to define whether these decisions were primarily driven by already existing long-term business strategies or current external economic conditions, and also what other factors played a role in the decision-making process. He found that the management of manufacturing companies during an economic recession involved decision-making on the basis of the current situation and economic conditions, i.e. the company's existing long-term business strategies did not affect operational management decisions during this period. Diskiene et al. (2019) identified the most important leadership competences, and then analyzed the impact of these competences on motivation, interest in work and employee initiative. To achieve this goal, they used a quantitative method along with a questionnaire. After analyzing the results, it was confirmed that leadership competences influence employee motivation, interest in work, etc.

Paik et al. (2019) conducted a decision-making survey of managers in the Republic of Korea and the USA with the same questionnaire but at different time intervals. After a questionnaire survey, they found that over the past two decades, Korean managers have relied more on the rule of utilitarian decision-making, which is also mostly used by US managers.

In their research studies, Hu et al. (2019) looked at the impact of managerial attention on innovation. They argued that managerial mindfulness is defined as a collective psychological state shared by members of senior management and can positively influence research and development intensity for company innovation. A research study was conducted in Zimbabwe at ZIMRA company on the effect of employee motivation in the workplace and employee engagement. They explored how organizations can help their employees achieve greater motivation performance. The survey used a quantitative method questionnaire, which was sent to 364 respondents through an online survey. Based on the results of the survey, they were able to assess the need to involve employees when deciding on issues related to workplace supervision. And this involvement can have an impact on results such as engagement and motivation in the workplace. In addition, they found that employee motivation mitigates the relationship between on-site supervision and employee engagement, requiring more investment in employee motivation if they are to remain involved in the work process (Tsvangirai \& Chinyamurindi, 2019).

Bryson \& White (2019) discussed whether formal human resource management practices are closely related to the performance of workers. The survey was conducted between employers and employees in the years 2004 and 2011. They found that when formal HRM procedures were introduced into the organization, the work motivation of employees was disrupted, so they must restore positive motivation by investing in HRM procedures, which are used by highly powerful working systems. Another interesting study on work motivation was conducted in South Korea among 281 hotel employees, where the goal was to discover a system by which work motiva- 
tion affects the work performance of service employees. Research results indicated that internal motivation positively affects the creativity of the employee and external motivation the opposite (Moon et al., 2019). Work motivation as a key factor for the success of organizations and the well-being of employees is also mentioned in the theory of motivation by its author Kanfer et al. (2017).

\section{RESEARCH OBJECTIVE, METHODOLOGY AND DATA}

The research objective of this study is to investigate whether the managers of manufacturing companies influence work satisfaction and motivation of employees by their decisions, behavior and management style and also what other factors influence employee motivation and their performance. The selected companies belong to the category of industrial production, specifically to the food industry, and with the number of employees, they rank among the medium-sized enterprises. The main reason for this choice is the fact that industrial production in Slovakia still has a very strong position due to its share in GDP, so we think it is interesting to focus on this sector. The questionnaire survey, which was conducted between May and July 2019, involved respondents working in various jobs, such as economists, office workers, technicians and others in manufacturing companies in Slovakia. 53 respondents were women and 34 men. As for the age category, employees aged 41-50 prevailed, the lowest representation was in the age category 31-40 years old. Of the respondents involved, the highest number of people had secondary education with a school-leaving certificate $(70 \%)$ and the lowest number represented those having secondary school without a school-leaving certificate with an apprenticeship certificate (12\%) and tertiary education $(12 \%)$. The largest group is made up of people who having worked for 5-10 years in the company and the least people have worked there for $0-5$ years. The questionnaire survey consisted of 14 questions. In the evaluation of the questionnaire survey, the following scientific methods were used:

Chi - square test - represents the extension of the chi-square goodness of fit test and it is based on the crosstab filled with observed frequencies, where the observed frequency oij is the frequency of the combination $x_{i} \wedge y_{j}$. The expected eij frequencies are those that correspond to the null hypothesis of the independence of two variables. The Chi-squared test is used to determine whether there is a significant difference between the expected frequencies and the observed frequencies. The Chi-square test verifies that the differences in actual and expected frequencies can only be random (variables are independent) or statistically significant (variables are dependent) (Chajdiak, 2009).

Chi-square formula for calculating values:

$\left.\chi^{2}=\sum((o i j-e i j) 2) / e i j\right)$

where:

oij $=$ observed frequencies,

eij $=$ expected frequencies. 
Fisher's exact test - is a statistical measure of association based on calculation of probabilities from a factorial formula. It can be used as an alternative test to the Chi-square in cases where the Chi-square tests are invalid due to low expected frequencies. For its calculation we used the IBM SPSS Statistics Program.

Cramér's V - is based on the Chi-square and it is used to measure the strength of the relationship between variables. The result takes values from 0 - no correlation between variables to 1 - complete correlation.

Formula for Cramér's V:

$V=\sqrt{\frac{x^{2}}{n(q-1)}}$

In questions no. $6,8,9$ and 13 , the hypotheses were set.

\section{RESULTS}

The results obtained from the questionnaire survey were put into the contingency table, graphed and analyzed using the methods of descriptive statistics.

Question no. 6: Which of the options motivates you the most to increase your work performance?

H0: There is a presumption that the wage factor will have more effective incentive power for the men than for the women.

H1: The wage factor does not have more effective incentive power for the men than for the women.

Tab. 1 - Calculation of the chi-square and exact test to question no. 6. Source: own research

\begin{tabular}{|l|l|l|l|l|}
\hline & Value & df & $\begin{array}{l}\text { Asymptotic } \\
\text { Significance } \\
(2 \text {-sided })\end{array}$ & $\begin{array}{l}\text { Exact Sig. } \\
\text { (2-sided) }\end{array}$ \\
\hline Pearson Chi-Square & 3.234 & 4 & 0.520 & 0.539 \\
\hline Fisher's Exact Test & 3.179 & & & $\mathbf{0 . 5 5 2}$ \\
\hline N of Valid Cases & 87 & & & \\
\hline
\end{tabular}

Source: own processing (2020)

Table 1 shows the calculation of the relationship between the choice of the "wage" factor and the gender of respondents at the significance level of $0.05 \%$. Since the conditions for using the Chi-square were not met ( $40 \%$ of the cells contained a lower expected frequency than 5), we calculated the Fisher's exact test. The calculated value is higher than the level of significance we have chosen, which indicates that we cannot confirm the null hypothesis. Therefore, a statistically significant relationship between gender and the choice of the 'wage' as the factor that motivates respondents the most to increase their work performance has not been confirmed, but the percentage of choice of this factor has already indicated that women $(40 \%)$ chose this option to a greater extent than men $(33 \%)$. 
Question no. 8: Do you find yourself sufficiently motivated by your manager?

H0: There is a presumption that women are more motivated by their manager than men.

H1: Women are not more motivated by their manager than men.

Tab. 2 - Calculation of the Chi-square and exact test to question no. 8. Source: own research

\begin{tabular}{|l|l|l|l|l|}
\hline & Value & df & $\begin{array}{l}\text { Asymptotic } \\
\text { Significance } \\
(2 \text {-sided })\end{array}$ & $\begin{array}{l}\text { Exact Sig. } \\
(2 \text {-sided })\end{array}$ \\
\hline Pearson Chi-Square & 2.475 & 2 & 0.290 & 0.304 \\
\hline Fisher's Exact Test & 2.410 & & & $\mathbf{0 . 3 4 0}$ \\
\hline N of Valid Cases & 87 & & & \\
\hline
\end{tabular}

Source: own processing (2020)

Table 2 shows the calculation of the relationship between the answer to the question of sufficient motivation by the manager and the gender of respondents. Again, we chose a significance level of $0.05 \%$. Since $20 \%$ of the cells did not contain an expected frequency $\geq 5$, we also calculated the Fisher's exact test. The results indicate that there is no significant relationship between the choice of answer to the question of sufficient motivation by the manager and the gender of respondents. Since this was a scaled question and respondents could choose one of three answers (strongly agree, agree, disagree), we calculated the mean and median by adding numerical values to the answers.

Tab. 3 - Mean and median to question no. 8. Source: own research

\begin{tabular}{|l|l|l|}
\hline Gender & Mean & Median \\
\hline Female & 1.92 & 2 \\
\hline Male & 1.97 & 2 \\
\hline
\end{tabular}

Source: own processing (2020)

As can be seen in Table 3, respondents of both genders are almost equally motivated by their manager. Based on mean and median, it can be interpreted that they agree to be sufficiently motivated by their manager.

Question no. 9: Why do you work in the company?

H0: There is a presumption that the financial evaluation will be the most homogeneous and dominant factor in the structure of motivational preferences.

H1: The financial evaluation will not be the most homogeneous and dominant factor in the motivational preference structure. 
Tab. 4 - Calculation of the Chi-square, exact test and Cramér's V to question no. 9

\begin{tabular}{|l|l|l|l|l|}
\hline & Value & df & $\begin{array}{l}\text { Asymptotic Significance } \\
(2 \text {-sided })\end{array}$ & $\begin{array}{l}\text { Exact Sig. } \\
(2 \text {-sided })\end{array}$ \\
\hline Pearson Chi-Square & 8.594 & 3 & 0.035 & 0.033 \\
\hline Fisher's Exact Test & 8.386 & & & $\mathbf{0 . 0 3 3}$ \\
\hline Cramér's V & $\mathbf{0 . 3 1 4}$ & & & 0.033 \\
\hline N of Valid Cases & 87 & & & \\
\hline
\end{tabular}

Source: own processing (2020)

Table 4 shows the calculation of the relationship between the choice of individual reasons/motivations for working in the surveyed enterprise and the gender of respondents. The calculation of the Chi-square as well as Fisher's exact test confirmed the statistically significant dependence between variables, which we subsequently quantified by Cramér's V. The value of 0.314 indicates a relatively strong association between the variables. Looking at the individual percentages of responses, we also found that for the women, the most dominant reason for working in this enterprise was qualifications and education, chosen by up to $54 \%$ of the women. For the men, the most dominant reason for working in this enterprise was the financial evaluation, which was chosen by $40 \%$ of the men, but only slightly exceeded the second most common answer. The second most frequent motivation for working in this enterprise, chosen by $37 \%$ of the men, was also qualifications and education.

Question no. 13: Does a superior manager influence your motivation and performance by his/ her decision-making and behavior?

H1: If managers' decisions change, this will affect employee motivation and performance.

H0: If managers' decisions change, this does not affect employee motivation.

Again we chose a scaled question, in this case with a four-stage scale (strongly agree, agree, disagree, strongly disagree), assigning numerical values to each answer. The following table (Table 5) shows the mean and median of the selected responses for both genders and together.

Tab. 5 - Mean and median to question no. 13. Source: own research

\begin{tabular}{|l|l|l|}
\hline Gender & Mean & Median \\
\hline Female & 3.31 & 4 \\
\hline Male & 2.74 & 3 \\
\hline Total & 3.15 & 3 \\
\hline
\end{tabular}

Source: own processing (2020)

Based on the results, we conclude that our research assumption has been confirmed. A change in managerial decisions will affect employee motivation. In the case of the women, on the basis of the median we can assess that a change in managerial decision-making will certainly affect their motivation (women strongly agree with this statement); men responded that a change in managerial decision-making will "rather affect" their motivation by answering "agree." We chose to verify the dependence on the gender of the respondents of their choice of answers by the Chisquare test. For this purpose, we divided the answers into two categories (agree and disagree). 
Tab. 6 - Calculation of the Chi-square for question no. 9. Source: own research

\begin{tabular}{|c|c|c|c|c|}
\hline Chi-Square Test & & & & \\
\hline & Value & $\mathrm{df}$ & $\begin{array}{l}\text { Asymptotic Significance } \\
\text { (2-sided) }\end{array}$ & Exact Sig. (2-sided) \\
\hline Pearson Chi-Square & 2.510 & 1 & 0.113 & 0.092 \\
\hline $\mathrm{N}$ of Valid Cases & 87 & & & \\
\hline
\end{tabular}

Source: own processing (2020)

Although the mean and median calculations indicated that women were more inclined to respond positively, the Chi-square calculation did not confirm a statistically significant dependence of responses to the respondents' gender. Although the value of 0.092 was close to the chosen level of significance $0.05 \%$, it was not lower. Nevertheless, based on the mean and the median, a change in managerial decisions will affect employee motivation.

We can conclude that within the chosen production enterprise, the wage factor is one of the most effective motivational factors, although the assumption that it has more effective incentive power for the men than for the women has not been confirmed. When it came to the question of which factors motivated employees to achieve higher work performance, for the men financial incentives and wages were equally identified as the most motivating factor. For the women, the most important motivating factor was wage, to a lesser extent financial rewards, and finally in the third place career progression. Only a small percentage of the men and women chose "recognition and praise" as the factor that motivates them most to achieve higher job performance. Specifically, only $14 \%$ of the men and $6 \%$ of the women indicated this option. In question no. 8 , we investigated whether employees felt sufficiently motivated by their superior manager. We assumed that women would answer more positively than men. The responses showed that only $8 \%$ of the women felt strongly motivated by their manager, but up to $50 \%$ of the women chose the answer "agree," which means they do feel motivated, but not strongly. $42 \%$ of the women do not feel sufficiently motivated by their superior manager. For the men, the "agree" option prevailed, chosen by up to $60 \%$ of the men. Only $12 \%$ of the men said they did not feel sufficiently motivated by their superior manager. In question no. 9, the respondents were asked why they work specifically for their particular company. We assumed that the financial evaluation would be the most homogeneous and dominant factor in the structure of motivational preferences, but this assumption was not confirmed. Of the options offered, the answer "qualifications and education" was the most frequent answer, with the second most frequently chosen answer "financial evaluation" and in third place "company's position on the market." For the men, financial evaluation was the most frequently chosen answer, while for the women it was the option "qualifications and education." Only less than $12 \%$ of the men and less than $4 \%$ of the women chose the option "offered benefits." Despite our expectations, the answers to the first three questions did not differ significantly between men and women. This suggests that the expectations of the men and women, as well as the factors that motivate them, are gradually unifying. In question no. 13, we focused on finding out whether the decision-making and approach of the superior manager influences the motivation and work performance of employees. We assumed that changes in managers' decisions and approach would affect employee motivation. This assumption has been confirmed. Up to $40 \%$ of the women chose "strongly agree," while for the men, it was over $32 \%$. 
$21 \%$ of the women opted for the "agree" option, and slightly more than $35 \%$ for the men. Almost $21 \%$ of the women chose the option "strongly disagree;" for the men, it was just under $15 \%$. In the case of the women, on the basis of the median, we can assess that a change in managerial decision-making will certainly affect their motivation (women strongly agree with this statement), while the men responded that a change in managerial decision-making will "rather affect" their motivation by answering "agree."

\section{DISCUSSION}

Our analysis of the current state of research in the subject area has shown that this topic is quite broad, and research should be focused on the various specific areas. At the same time, the most appropriate method for examining employee motivation was found to be qualitative research carried out in the conditions of real companies or institutions. The unifying element of all the analyzed scientific studies is the use of a questionnaire method, which proved to be the most appropriate.

In our research, we examined whether the managers of manufacturing companies influenced the job satisfaction and motivation of employees by their decision-making, behavior and management style, as well as what other factors influence the motivation of employees and their work performance. We focused on motivation factors for work performance as well as asked employees whether they are sufficiently motivated by their supervisors, why they work in the company, and whether their work performance is influenced by the decision-making and behavior of their superiors. Our research has shown that the wage factor does not have as much of an effective incentive power for the men as for the women, that women are not more motivated by their superior than men, that salary will not be the most homogeneous and dominant factor in the motivational preference structure, and what ultimately affects the motivation of employees is changes in their manager's decisions. We can link this to the research of Nientied \& Toska (2019), who found that monetary valuation and career opportunities are not the most critical motivational factors and do not have such motivational strength. Conversely, research by Kocabiyikoglu \& Popescu (2007) showed that salary is considered a necessary motivating factor. Diskiene et al. (2019) also focused on the sub-issue of the influence of managerial decision-making on employee in terms of motivation. Their research conducted in Lithuania showed that the results varied considerably depending on age, gender and other characteristics. In our research there were also differences, but especially in the different perceptions of salary as a motivational factor by men and women. Paik et al. (2019), who also addressed this issue, based their research on the premise that business ethics is a function of culture and time. They attempted to explore two important questions to determine whether national differences in managerial ethical philosophies remain over time and whether the relationship between thinking style and ethical decision-making is consistent across different national contexts. This is also a very interesting idea in which we could direct our research in the future, although with the difference that the issue of national views over time would be analyzed not through the decisions of managers, but the reactions of employees to managerial decisions and management styles. 


\section{CONCLUSIONS}

In our research, we focused on answering questions regarding the relationship between managerial decision-making and employee motivation in manufacturing companies. It was determined that the factor and benefit that affects employees most is motivation, which leads them to higher work performance. We also sought to determine to what extent the manager influences motivation and performance of employees by his/her decisions and approach. The results indicate that under the conditions of the chosen manufacturing companies, employees are more motivated by financial rewards and wages than by recognition and praise from the superior manager. A relatively important motivating factor is also the possibility of career progression and the work itself. Regarding the motivation of employees by the supervisor, we can consider men as more motivated, while most women felt partially motivated. In finding out whether the decision-making and approach of the superior influences the motivation and work performance of employees, we found mostly positive answers. Most of the respondents stated that by changing the decisions and approach, the supervisor would influence their work motivation. Although the results are statistically significant, the number of respondents involved in research can be perceived as a limitation of the study. A larger research sample would also make it possible to compare results for different categories of workers. We believe that it would be interesting in the future to follow up on this research by conducting the same survey at a public institution and to compare the results obtained with the present results to determine if the motivating factors differ significantly among diverse sets of conditions.

\section{References}

1. Bratu, M. L., \& Cioca, L. I. (2019). Modelling Human Behaviour through Game Theory in Order to increase the Quality of Work and the Quality of Life of Employees through Managerial Strategies Appropriate to Individual and Group Personality. Quality - Access to Success, 19 (167), 54-58. Retrieved from: https://www.srac.ro/calitatea/en/arhiva_journal. html\#2019

2. Bryson, A., \& White, M. (2019). HRM and Small-Firm Employee Motivation: Before and After the Great Recession. IRL Review, 72 (3), 749-773. https://doi. org/10.1177\%2F0019793918774524

3. Boselie, S. P. (2014). Strategic Human Resonce Management: A balanced approach. London: McGraw Hill Education.

4. Dionne, S. D., Sayama, H., \& Yammarino, F. J. (2019). Diversity and Social Network Structure in Collective Decision Making: Evolutionary Perspectives with Agent-Based Simulations. Complexity, 1-16. https://doi.org/10.1155/2019/7591072

5. Diskiene, D., Pauliene, R., \& Ramanauskaite, D. (2019). Relationships between Leadership Competencies and Employees' Motivation, Initiative and Interest to Work. Montenegrin Journal of Economics, 15 (1), 113-129. https://doi.org/10.14254/1800-5845/2019.15-1.9

6. Hu, Y., Zhao, X., \& Chen, Y. (2019). The Influence of Managerial Mindfulness on Innovation: Evidence from China. Sustainability, 11, 2914. https://doi.org/10.3390/su11102914

7. Chajdiak, J. (2009). Śtatistika jednoducho v Exceli. Bratislava: STATIS. 
8. Kanfer, R., Frese, M., \& Johnson, R. E. (2017). Motivation Related to Work: A Century of Progress. Journal of Applied Psychology, 102 (3), 338-355. https://doi.org/10.1037/apl0000133

9. Kljajić-Dervić, M., Matotek, Ž., \& Sumar, S. (2019). Identification of problems which limit an increase of effectiveness of manufacturing companies. Interdisciplinary management research XV, 465-491. Retrieved from: https://zebrica.app.box.com/s/htxo0y204lqycuvjvbz2v9znd832whuf

10. Kocabiyikoglu, A., \& Popescu, I. (2007). Managerial Motivation Dynamics and Incentives. Management Science, 53 (5), 834-848. https://doi.org/10.1287/mnsc.1060.0640

11. Magnier- Watanabe, R., Benton, C. F., Uchida, T., \& Orsini, P. (2019). Designing Jobs to Make Employees Happy? Focus on Job Satisfaction First. Social Science Japan Journal, 22 (1), 85-107. https://doi.org/10.1093/ssij/jyy040

12. Miao, Q., Eva, N., Newman, A., \& Schwarz, G. (2019). Public service motivation and performance: The role of organizational identification. Public Money \& Management, 39 (2), 77-85. https://doi.org/10.1080/09540962.2018.1556004

13. Moon, T. W., Hur, W. M., \& Hyun, S. S. (2019). How Service Employees’ Work Motivations Lead to Job Performance: The Role of Service Employees' Job Creativity and Customer Orientation. Current psychology, 38, 517-532. https://doi.org/10.1007/s12144-017-9630-8

14. Nientied, P., \& Toska. (2019). Motivation of knowledge workers - the case of Albania. Organizacija, 52 (1), 33-45. Retrieved from http://organizacija.fov.uni-mb.si/index.php/ organizacija/article/view/929

15. Paik, Y., Lee, JM., \& Pak, YS. (2019). Convergence in international business ethics. Comparative study of ethical philosophies, thinking and ethical decision-making between American and Korean managers. Journal of Business Ethics, 156, 139-855. https://doi. org/10.1007/s10551-017-3629-9

16. Permatasari, A., Amadea, C., Anggadwita,G., \& Alamanda, D. T. (2019). An Integrated Human Resources Model in Manufacturing Companies: A case of Indonesia. IOP Conference Series: Materials Science and Engineering, 505 (1), 1-8. https://doi.org/10.1088/1757899X/505/1/012029

17. Powell, A. R., \& Buede, M. D. (2009). The project managers guide to making successful decision. Wienna: Management concepts.

18. Silva, R. G., Moraes, L., Barrichello, A., Damásio de Aquino, J., Cusciano, D., \& Fereira de Oliveira, D. F. (2019). Fatores que influenciam a tomada de decisão para a melhoria da segurança e saúde dos trabalhadores: a percepção de profissionais especializados. Revista Brasileira de Medicina do Trabalho 17 (1), 88-89. Retrieved from: https://www.researchgate.net/ publication/333493825_Fatores_que_influenciam_a_tomada_de_decisao_para_a_melhoria_ da_seguranca_e_saude_dos_trabalhadores_a_percepcao_de_profissionais_especializados

19. Schwartz, M. S. (2016). Ethical decision-making theory: An integrated approach. Journal of Business Ethics, 139, 755-776. https://doi.org/10.1007/s10551-015-2886-8

20. Tabatabaei, M. H., Amiri, M., Firouzabadi, SMAK., Ghahremanloo, M., Keshavarz Ghorabaee, M., \& Saparauskas, J. (2019). A New Group Decision-Making Model based on BWM and its Application to Managerial Problems. Transformations in Business \& Economics, 2 (47), 197-214. Retrieved from: https://www.researchgate.net/journal/1648-4460_ Transformations_in_Business_and_Economics 
21. Tsvangirai, F. P., \& Chinyamurindi, W. T. (2019). The moderating effect of employee motivation on workplace surveillance and employee engagement amongst employees at the Zimbabwe Revenue Authority. S A Journal of Human Resource Management, 17, 8. https://doi. org/10.4102/sajhrm.v17i0.1106

22. Vojtovič, S. (2016). Management decision-making process in the times of economic volatility. Proceedings of the 1st international conference contemporary issues in theory and practice of management: CITPM 2016, 459-464. Retrieved from http://citpm.wz.pcz.pl/ proceedings-2016.html

\section{Contact information}

doc. Ing. Jozef Habanik, PhD.

Alexander Dubček University of Trenčin

Faculty of Economic and Social Relations

Department of Public Administration and Regional Economics

Slovakia

E-mail:jozef.habanik@tnuni.sk

Ing. Adriana Martosova

Alexander Dubček University of Trenčin

Faculty of Economic and Social Relations

Department of Management and Human Resources

Slovakia

E-mail:adriana.martosova@tnuni.sk

Ing. Natalia Letkova

Alexander Dubceke University of Trenčin

Faculty of Economic and Social Relations

Department of Management and Human Resources

Slovakia

E-mail:natalia.letkova@tnuni.sk

ORCID: 0000-0001-9531-5715 